\title{
The impact of conventional and organic farming on soil biodiversity conservation: a case study on termites in the long-term farming systems comparison trials in Kenya
}

John J. Anyango 1,2, David Bautze ${ }^{3^{*}} \mathbb{1}$, Komi K. M. Fiaboe ${ }^{1}$, Zipporah O. Lagat ${ }^{4}$, Anne W. Muriuki ${ }^{2}$, Sibylle Stöcklii, Judith Riedel ${ }^{3}$, Gladys K. Onyambu'4, Martha W. Musyoka', Edward N. Karanja' and Noah Adamtey ${ }^{3}$

\begin{abstract}
Background: A long-term experiment at two trial sites in Kenya has been on-going since 2007 to assess the effect of organic and conventional farming systems on productivity, profitability and sustainability. During these trials the presence of significant numbers of termites (Isoptera) was observed. Termites are major soil macrofauna and within literature they are either depict as 'pests' or as important indicator for environmental sustainability. The extent by which termites may be managed to avoid crop damage, but improve sustainability of farming systems is worthwhile to understand. Therefore, a study on termites was added to the long-term experiments in Kenya. The objectives of the study were to quantify the effect of organic (Org) and conventional (Conv) farming systems at two input levels (low and high) on the abundance, incidence, diversity and foraging activities of termites.

Results: The results showed higher termite abundance, incidence, activity and diversity in Org-High compared to Conv-High, Conv-Low and Org-Low. However, the termite presence in each system was also dependent on soil depth, trial site and cropping season. During the experiment, nine different termite genera were identified, that belong to three subfamilies: (i) Macrotermitinae (genera: Allodontotermes, Ancistrotermes, Macrotermes, Microtermes, Odontotermes and Pseudocanthotermes), (ii) Termitinae (Amitermes and Cubitermes) and (iii) Nasutitiermitinae (Trinervitermes).

Conclusions: We hypothesize that the presence of termites within the different farming systems might be influenced by the types of input applied, the soil moisture content and the occurrence of natural enemies. Our findings further demonstrate that the organic high input system attracts termites, which are an important, and often beneficial, component of soil fauna. This further increases the potential of such systems in enhancing sustainable agricultural production in Kenya.
\end{abstract}

Keywords: Farming systems, Organic farming, Long-term trial, Soil macrofauna, Termite abundance, Termite diversity, Termite activity

*Correspondence: david.bautze@fibl.org

${ }^{3}$ Department of International Cooperation, Research Institute of Organic Agriculture (FiBL), Ackerstrasse 113, P.O. Box 219, 5070 Frick, Switzerland Full list of author information is available at the end of the article

\section{Background}

Stagnant or declining farm productivity in the tropics has been a cause for concern for several decades, mainly due to declining soil fertility and land degradation following the expansion of conventional farming practices [1]. Restoration of soil quality and fertility is a major challenge to local farmers, policy makers and the international

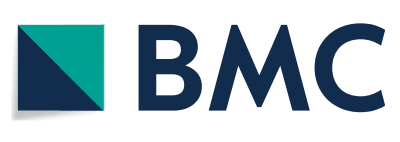

(0) The Author(s) 2020. This article is licensed under a Creative Commons Attribution 4.0 International License, which permits use, sharing, adaptation, distribution and reproduction in any medium or format, as long as you give appropriate credit to the original author(s) and the source, provide a link to the Creative Commons licence, and indicate if changes were made. The images or other third party material in this article are included in the article's Creative Commons licence, unless indicated otherwise in a credit line to the material. If material is not included in the article's Creative Commons licence and your intended use is not permitted by statutory regulation or exceeds the permitted use, you will need to obtain permission directly from the copyright holder. To view a copy of this licence, visit http://creativeco mmons.org/licenses/by/4.0/. The Creative Commons Public Domain Dedication waiver (http://creativecommons.org/publicdomain/ zero/1.0// applies to the data made available in this article, unless otherwise stated in a credit line to the data. 
agricultural research community. Termites, together with earthworms and ants, are major part of the soil macrofauna and play an important role in enhancing soil quality [2]. However, whereas the effects of earthworms on soil quality have been extensively studied, the effects of termites are not well understood, despite their quantitative importance in many tropical agricultural soils [3].

Within literature there is a distinct dichotomy between that which depicts termites as 'pests' and the ecological literature that argues that they play a crucial role as "ecosystem engineers" [4]. Termites (as a pest) often cause partial or total destruction of older crops that have been cultivated for a longer period [5], non-native plants [6] and crops grown during drier seasons [7]. They also damage plants with a high content of lignin and cellulose [8] and crops grown in areas that have been recently cleared or burnt off [9]. The damage can be enhanced by the depletion of alternative food sources for termites or due to loss of their natural enemies [10]. Termites occasionally infest a wide range of host plants in both forestry and agriculture (e.g. maize, cassava, ground nuts, sorghum and sugar cane, rice; and pastures and plantation) where the damage can result in huge losses $[4,11]$. Yield losses ranging from 50 to $100 \%$ are occasionally reported [12] and it is estimated that globally, termite control costs an estimated $\$ 20$ billion annually [13].

In contrast, results from previous studies have shown that a majority of termite species are encountered in agro ecological systems, but cannot be described as crop pests. Their presence is not correlating with yield losses, instead termites have key ecological functions for soil health $[6,14]$. In combination with some agronomic inputs (e.g. mulch), termite presence has been found to improve water permeability $[15,16]$ and nutrient availability [17]. Similarly a direct link exists between higher termite abundance and enriched organic matter contents $[18,19]$, increased soil porosity [20], released plant nutrients and stable soil micro-aggregates [21]. Several SSA countries use termite mounds to modify soils for crop production [22], with some communities spreading the terminarium into agricultural lands to achieve maximum crop yields reported [22, 23].

The extent by which termites may be managed to avoid crop damage, but improve soil quality is worthwhile to understand. However, there is some knowledge existing on how biophysical and management factors affect termite abundance, diversity and activity [24, 25], but on the extent how complex farming systems affect termites only little knowledge exists [26, 27]. In Kenya, Long-term Farming Systems Comparisons trials (SysCom; $[28,29]$ ) have been on-going since 2007 at Chuka (Tharaka Nithi County) and at Thika (Murang'a County) to provide evidence on productivity, profitability and sustainability of the different agricultural production systems. In the experiment organic (Org) and conventional (Conv) farming systems are compared at high input levels representing commercial large scale production (high inputs of fertilizer and irrigation) and low input levels representing small holder production, largely for subsistence use (low inputs of fertilizer and rain fed). A detailed study on termites was introduced into the trials to determine how the farming systems (Conv-Low, Org-Low, Conv-High and Org-High) in the long-term experiment influence (i) abundance, incidence and foraging activities of termites (total and casts), and (ii) diversity of termite genus. Furthermore, the study should reveal how the different environmental conditions (trial sites Chuka and Thika), crop patterns (cropping seasons with different crops) and soil depths (substrate, topsoil and subsoil) influence the termite presence, activity and diversity in the various farming systems. From past termite observation in the long-term experiment, our hypotheses was that more termites are present in the farming system Org-High compared to the other farming system. Thus, activity and most probably diversity will be higher in this farming system. Establishing such knowledge can contribute to determining the environmental sustainability of farming systems.

\section{Results}

The abundance of, and incidence index for total numbers of termites and termite castes

The study sampled a total of over 60,000 termites from the long-term farming systems comparison trials at the two sites. The results revealed general effects of the different farming systems on the average abundance of, and incidence index for termites (Fig. 1). The Org-High farming system had the highest average abundance of total number of termites in the substrate $(37.9 \pm 1.5$ termites per $\left.40,000 \mathrm{~cm}^{2}\right)$ and in the soil $(28.5 \pm 0.5$ termites per $4000 \mathrm{~cm}^{3}$ ) over all cropping seasons and trial sites. In all the other farming systems average termite abundance was significantly lower: 13-15 times less in the substrate (value range from 2.6 to 2.9 ) and 6-7 times lower in the soil (value range from 3.9 to 4.6). The results of the average incidence index showed a similar pattern, with Org-High also having the highest values in the substrate $\left(2.8 \pm 0.1\right.$ per $\left.40,000 \mathrm{~cm}^{2}\right)$ and the soil $(2.7 \pm 0.1$ per $4000 \mathrm{~cm}^{3}$ ) over all the cropping seasons and trial sites. These values were 4.5 and 3 times higher respectively than those found in the other systems (0.6 and 0.9-1.1 respectively).

There were several significant interactions between the factor farming system and the other factors trial site, soil depth and cropping season on the average abundance of and the incidence index for termites 

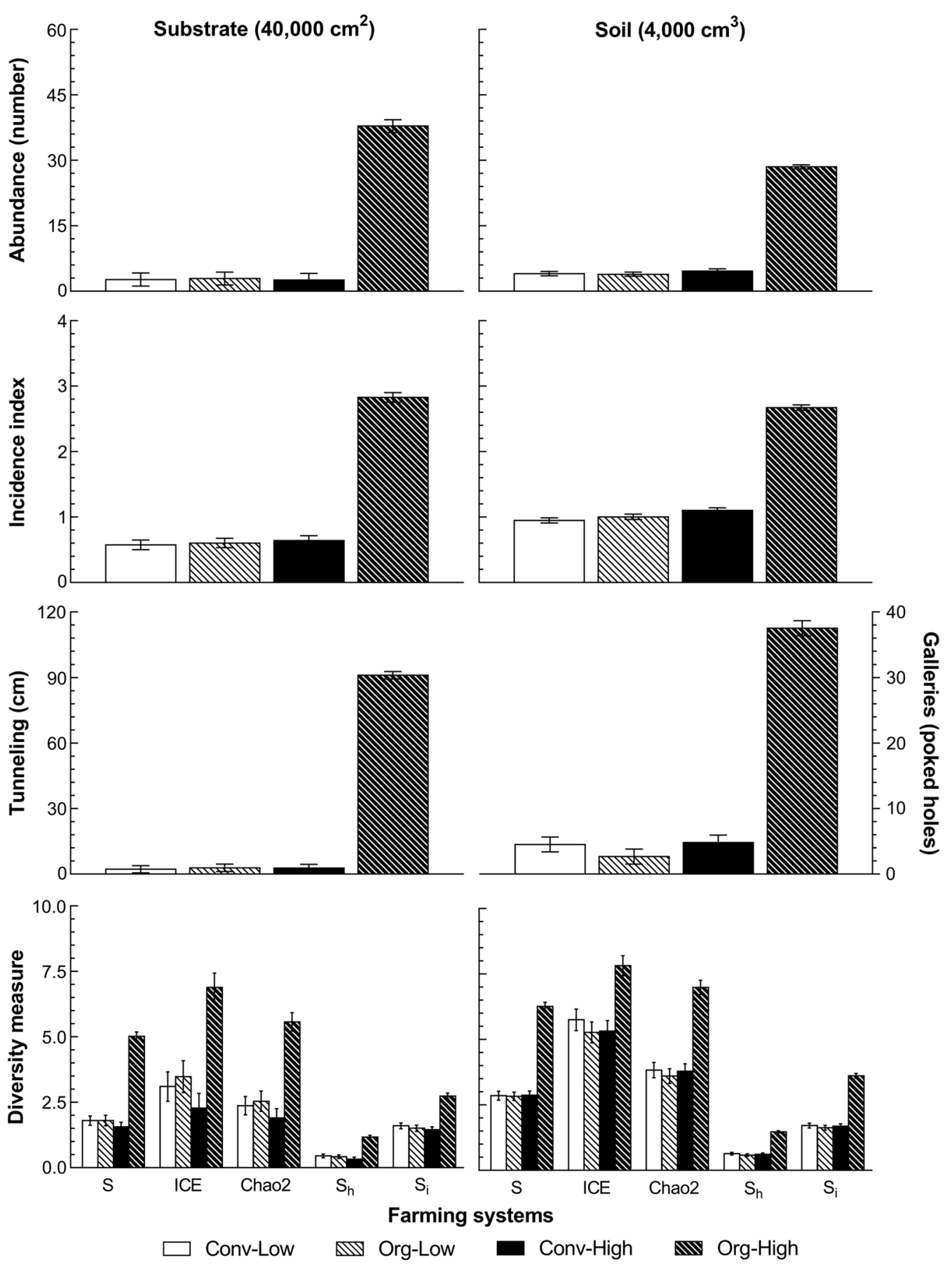

Fig. 1 The summarized effect of farming systems on termite number, presence, activity and diversity. The average abundance of, incidence index for, tunneling/galleries activity and diversity measures of the total number of termites in the substrate and soil in long-term farming systems comparisons trials at Chuka and Thika, the Central Highlands of Kenya (error bars: \pm standard error of means)

(Additional file 1: Table S1). We will further only show the results on average incidence index, because average abundance showed similar results and did not further enhance the knowledge on the influence of farming systems. A graphical representation of the average incidence index for the total number of termites in the farming systems for all cropping seasons, soil depths and trial sites can be seen in Fig. 2. 


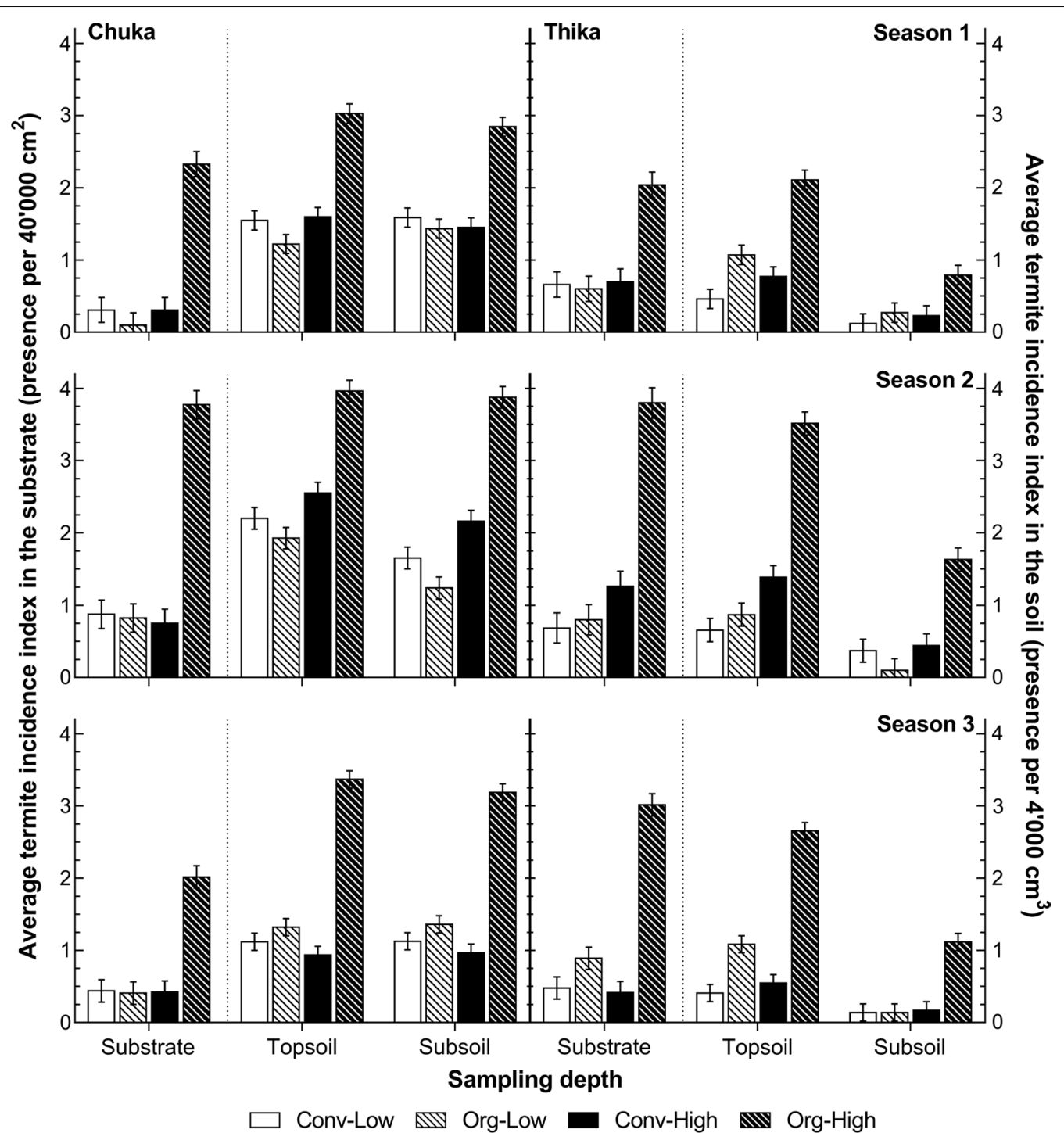

Fig. 2 The effect of farming system, trial site, cropping season and soil depth on termite incidence. The average termite incidence index in the substrate and the soil in the 1st, 2nd and 3rd season at Chuka and Thika, the Central Highlands of Kenya (error bars: \pm standard error of means)

\section{The average incidence index for termites in the substrate}

The statistical analysis of all factors revealed a farming system * soil depth * trial site interaction was significant $(p<0.01)$ and showed significantly higher values in Org-High than in the other farming systems in every season at both sites. There were only significant seasonal differences within the Org-High system. At Chuka, Org-High showed the highest values in the 2nd season $(3.8 \pm 0.2)$, which was significantly higher than those found in the same system at the same site in the 1st $(2.3 \pm 0.2)$ and 3 rd season $(2.0 \pm 0.2)$. At Thika the highest values in the Org-High system were found in the 2nd $(3.8 \pm 0.2)$ and 3rd season (3.0 \pm 0.2$)$, which were significantly higher than in the 1 st season
$(2.0 \pm 0.2)$. In addition, the values in the Org-High system in the $3^{\text {rd }}$ season at Thika were significantly higher $(3.0 \pm 0.2)$ than at Chuka $(2.0 \pm 0.2)$, which showed a difference that was not evident in the other seasons. None of the other farming systems showed such significant differences between seasons or trial sites for the average incidence index of total number of termites in the substrate.

In general, the average abundance of, and the incidence index for, termite castes i.e. workers (2084 individuals found) and immature individuals (9759) in the substrate followed the same patterns as for the total number of termites. This is further confirmed by the significant positive $(p<0.001)$ correlation of the abundance of termite 
workers $(r=0.99)$ and immature termites $(r=1.00)$ with the total number of termites in the substrate (Table 1 ). The average abundance of termite soldiers in the substrate (997 individuals found) showed a smaller, but nonetheless significant $(p<0.001)$ positive correlation $(r=0.76)$ with the abundance of the total number of termites in the substrate.

\section{The average incidence index for termites in the soil}

The statistical analysis revealed, that only two of the three three-way interactions were significant for the incidence index of total number of termites (Additional file 1: Table S1). Both interactions showed that termites were significantly more frequently present (i) on the Org-High plots than in all other systems, and (ii) at Chuka compared to Thika. Furthermore, the significant farming system * trial site * soil depth $(p<0.001)$ interaction revealed some further significant differences within the farming systems. At Thika the incidence of termites in three farming systems (Org-Low, Conv-High and Org-High) was significantly higher in the topsoil $(1.0 \pm 0.1,0.9 \pm 0.1$ and $2.8 \pm 0.1$ respectively) than in the subsoil $(0.2 \pm 0.1$, $0.3 \pm 0.1$ and $1.2 \pm 0.1)$. Such a distinction did not appear in the Conv-Low system at Thika or in any of the farming systems at Chuka.

The significant farming system * trial site * cropping season $(p<0.01)$ interaction showed no significant differences between the farming systems additionally to the one mentioned above, although the interaction showed significant seasonal and inter-site differences within the two high input systems. The values for Conv-High and Org-High in the 2nd season at Chuka $(2.4 \pm 0.1$ and $3.9 \pm 0.1)$ and Thika $(0.9 \pm 0.1$ and $2.6 \pm 0.1)$ were significantly higher than in the 1st season $(1.5 \pm 0.1$ and $2.9 \pm 0.1$ at Chuka; $0.5 \pm 0.1$ and $1.5 \pm 0.1$ at Thika), and in the 3rd season $(1.0 \pm 0.1$ and $2.9 \pm 0.1$ at Chuka; $0.4 \pm 0.1$ and $1.9 \pm 0.1$ at Thika). No significant differences between the seasons were found within the low input systems.

In the soil (as in the substrate) the average abundance of, and the incidence index for, the termite castes i.e. the termite workers (7800 individuals found) and immature individuals $(39,891)$ followed the same pattern as the total number of termites. This is also confirmed by the significant positive $(p<0.001)$ correlation of the abundance of termite workers $(r=0.99)$ and immature individuals $(r=1.00)$ with the total number of termites in the soil (Table 1). The average abundance of termite soldiers (4030 individuals found) showed a smaller, but nonetheless significant $(p<0.001)$ positive correlation $(\mathrm{r}=0.73)$ with total termite abundance in the soil.

\section{Termite activity: tunneling in the substrate and galleries in the soil}

This study also determined termite activity by measuring tunneling (in $\mathrm{cm}$ ) within substrates, and the numbers of galleries (pocked holes) within soil profiles. Both these determinants were generally affected by the farming systems, as shown in Fig. 1. The Org-High farming system recorded the average highest values for tunneling $(87.9 \pm 12.4)$ and gallery activity $(36.6 \pm 3.3)$ over all soil depths, cropping seasons and trial sites. These figures were 30-40 and 8-14 times higher respectively than the values for tunneling (range 2.01-2.81) and gallery activity (range 2.58-4.34) recorded within the other farming systems.

As with the other indicators we have described (average abundance and the incidence index), termite activity was significantly affected by other factors, including the trial site, cropping season, soil depths and interactions between these factors and the farming systems (Additional file 1: Table S1). However, no additional trends could be extracted from the data on activity, which would enhance the knowledge on termite behavior. The

Table 1 The correlation of total number of termites and termite casts and activity

\begin{tabular}{|c|c|c|c|c|c|c|}
\hline (Substrate/soil) & Total & Worker & Soldier & Immature & Tunneling & Gallery $^{a}$ \\
\hline Total & 1.00 & $0.99^{* * *} / 0.99^{* * *}$ & $0.76^{* * *} / 0.73^{* * *}$ & $1.00^{* * *} / 1.00^{* * *}$ & $0.60^{* * *} / \mathrm{na}$ & $\mathrm{na} / 0.50^{* * *}$ \\
\hline Worker & & 1.00 & $0.73^{* * *} / 0.68^{* * *}$ & $0.99^{* * *} / 0.99^{* * *}$ & $0.59^{* * *} /$ na & $\mathrm{na} / 0.50^{* * *}$ \\
\hline Soldier & & & 1.00 & $0.73^{* * *} / 0.68^{* * *}$ & $0.62^{* * *} /$ na & $\mathrm{na} / 0.35^{* * *}$ \\
\hline Immature & & & & 1.00 & $0.59 * * * /$ na & $\mathrm{na} / 0.50^{* * *}$ \\
\hline Tunneling & & & & & 1.00 & na \\
\hline Gallery & & & & & & 1.00 \\
\hline
\end{tabular}

The correlation (Pearson-r) of termite abundance between the total number of termites, termite castes and tunneling and gallery activity in the substrate (left hand value) and the soil (right hand value) in the long-term farming systems comparisons trial sites at Chuka and Thika, the Central Highlands of Kenya na not applicable

a The correlation between tunneling and gallery activity was only calculated for substrate or soil, as the activities were measured at different depths; NB: Significant correlations between total number of termites, termite caste and termite activity are indicated by ${ }^{*}(p<0.05),{ }^{* *}(p<0.01)$ or ${ }^{* *}(p<0.001)$ 
trends are similar to the already revealed trends in abundance and incidence. This is also shown by the significant positive $(p<0.001)$ correlation between average termite tunneling and gallery activities $(r=0.60$ and 0.50 respectively) with total termite abundance in the substrate and soil (Table 1).

\section{Diversity measures for termite genera in the substrate and soil}

A total of 2669 identifiable termite soldiers was found at Chuka and 2358 at Thika, belonging to 9 termite genera, from three sub-families: (i) Macrotermitinae (genera: Allodontotermes, Ancistrotermes, Macrotermes, Microtermes, Odontotermes and Pseudocanthotermes), (ii) Termitinae (Amitermes and Cubitermes) and (iii) Nasutitiermitinae (Trinervitermes). Macrotermes (1641 individuals) and Microtermes (1535) were the most abundant and Ancistrotermes (36) and Allodontotermes (37) the least abundant. Allodontotermes and Ancistrotermes were exclusively found at Chuka and Odontotermes only occurred at Thika.

In general, the highest values for species richness (S), the incidence-based coverage estimator of species richness (ICE), the Chao2 estimator of species richness, the Shannon index $\left(\mathrm{S}_{\mathrm{h}}\right)$ and the inverse Simpson index $\left(\mathrm{S}_{\mathrm{i}}\right)$ were all found in the substrate, top and subsoil of the Org-High farming system (Fig. 1). The other farming systems generally recorded lower values for these diversity measures. Nonetheless, other factors and interactions between the farming system and other factors, such as soil depth, trial site and cropping season were found to be significant in both the substrate and soil (Additional file 1: Table S2).

In the substrate, all the diversity measures were significantly affected by the farming system $(p<0.001)$ without significant interactions (except for $S_{\mathrm{i}}$ ). The Org-High farming system showed significantly higher values for $\mathrm{S}$ (5.02), ICE (6.89), Chao2 (5.57) and $\mathrm{S}_{\mathrm{h}}$ (1.17) than all the other farming systems. The farming system * trial site interaction was significant for $\mathrm{S}_{\mathrm{i}}(p<0.001)$ and with OrgHigh having significantly higher $S_{i}$ values (3.53) than the other farming systems at Thika (which ranged from 1.55 to 1.85). There were significant seasonal differences for $\mathrm{S}$ and Chao $2(p<0.001$ and $<0.05)$, which were significantly higher in the 3 rd season (3.06 and 3.74 respectively) than in the 1st season (2.25 and 2.65) and also for $\mathrm{S}$ in the 2nd season (2.32). The species richness (S), Chao2 and Shannon Index $\left(\mathrm{S}_{\mathrm{h}}\right)$ values showed a significant site factor $(p<0.001,<0.05$ and $<0.001$ respectively) with significantly higher values recorded at Thika (3.02, 3.66 and $0.75)$ than at Chuka (2.07, 2.53 and 0.43$)$.

Similar patterns were found in the soil. The farming system factor was significant $(p<0.001)$ for all the diversity measures, but significantly interacted with at least one other factor (with the exception of $\mathrm{S}_{\mathrm{i}}$ ). For species richness $(S)$ a significant farming system * season interaction emerged, with Org-High having significantly higher values (1st season 5.93, 2nd 6.39 and 3rd 6.46) than all other farming systems in all three seasons of the study. In the Conv-High farming system there were significant differences between the 1st (2.43) and 2nd season (3.64). The statistics for the incidence-based coverage estimator of species richness (ICE) in the soil showed a significant interactions with farming system and all other factors. There was a significant farming system " soil depth interaction $(p<0.01)$ with the values for ICE in the subsoil at being significantly higher in Org-High (8.21) than in Conv-High and Org-Low (4.71 and 4.28). The farming system " cropping season interaction $(p<0.05)$ revealed significant differences in diversity between the farming systems in the 1st and 3rd seasons. In both seasons Org-High showed significantly higher values (1st 7.88; 3rd 8.49) than ConvHigh (1st 4.26; 3rd 5.32). In the 3rd season the ICE for Org-High was even higher than the value for Conv-Low (5.14). The last significant interaction, between farming system and trial site $(p<0.01)$, showed no differences between the farming systems at Chuka, but at Thika the ICE for Org-High (7.45) was significantly higher than for all the other farming systems (range 3.44-4.19). The statistical analysis of the Chao 2 values revealed two significant interactions: The first, between farming system and soil depth $(p<0.05)$ showed that the Chao2 values in the top and subsoil in Org-High (6.96 and 7.01) were significantly higher than all the other values found in all the other systems (ranging from 2.89 to 4.45). Another interaction, between farming system and season $(p<0.05)$, showed the Chao 2 value for Org-High in the 1st (7.10) and 3rd seasons (7.26) to be significantly higher than all the other values found, excluding the value for Org-High in the 2nd season (6.60) (which was not a significant difference in relation to the other seasons' values). The statistical analysis of the Shannon index $S_{h}$ revealed a significant farming system * soil depth interaction $(p<0.01)$, with all the values for OrgHigh in the top and subsoil (1.53 and 1.41) being significantly higher than in all other systems at both depths. The inverted Simpson index $\mathrm{S}_{\mathrm{i}}$ only showed significant effects for farming system and soil depth $(p<0.001)$ : Org-High (3.61) scored significantly higher on this criteria than all other farming systems (range 1.64-1.71) and the topsoil values were significantly higher (2.36) than those for the subsoil (1.98). 


\section{Discussion}

\section{The effect of farming systems on termite abundance,} incidence index, activity and diversity

The termite populations occurred in varying abundances, incidences and diversities, all of which were consistently affected by the farming systems. Termite populations, activity and diversity were generally higher under the Org-High farming system than under the other farming systems (Conv-Low, Org-Low and Conv-High). The organic based inputs used in Org-High could have been among the main reasons why these plots attracted far more termites. Each season the Org-High plots received FYM-compost $\left(11.3 \mathrm{t} \mathrm{ha}^{-1}\right)$, Tithonia mulch $\left(5.4 \mathrm{t} \mathrm{ha}^{-1}\right)$, Tithonia tea $\left(3.9 \mathrm{t} \mathrm{ha}^{-1}\right)$ and rock phosphate $\left(364 \mathrm{~kg} \mathrm{ha}^{-1}\right)$. We hypothesize that the termites were more likely to inhabit these plots as these inputs provided preferred food sources. Refs. [30-32] have all reported similar results, as organic inputs contain cellulose materials that are generally preferred by the termites. They also noted that such inputs release gases that attract termites in large numbers. The cover crop (Mucuna) and the mulch material that was used (Tithonia in all seasons and rice mulch in the 1st and 3rd seasons) could have further increased the termite population in Org-High plots. A similar effect was also observed in a study by [33]. The lower termite abundance, incidence and activity observed in the other three farming systems was most probably due to their receiving fewer organic inputs and a result of the use of inorganic chemical fertilizers in the conventional systems. Similar results have been reported by [6].

Another possible explanation for the higher termite population, activity and diversity in the Org-High plots could be the irrigation that these plots occasionally received during dry spells. While the Conv-High plots also received irrigation water the Org-High plots were less liable to evapotranspiration from the topsoil and substrate due to the presence of cover crops and mulch. Such an environment is likely to be more conducive for termite survival and growth as it provides a more stable environment in which termites can break down and mix the organic fertilizer inputs using their saliva, excrete, and faecal pellets. Refs. [34-36] have reported in earlier studies that such environments are ideal for termite populations to thrive.

The generally low termite abundance in the conventional farming systems could also be attributed to the synthetic pesticides applied. Other authors found that synthetic pesticide can be highly effective [37, 38], but also varies depending on the applied management practices $[39,40]$. In the current trial effectiveness of the synthetic pesticides was also generally rated as varied i.e. being effective over vegetative into early maturity of maize crop but fairly ineffective during later stages. However, we generally observed that termite abundance decreased in both high input system (conventional and organic) after pesticide specifically against termites (Dragnet, Concord and Metarhizium anisopliae) were applied. The Metarhizium anisopliae fungus in the OrgHigh system seemed to be effective in controlling termites as shown also by other authors [41]. Despite the use of pesticide in both high input system, termite abundance was always higher in the organic system-before and after the application. However, chemical pesticides can have severe side effects on farmers health or ecosystem functions [42, 43]. Bio-pesticides like botanicals or biological control agents could be environmental friendly and low-risk alternatives [44-47].

Overall, the recorded termite diversity in the Org-High system is similar to results in studies from Zimbabwe [48] and Nigeria [49], where 7 and 10 genera (respectively) were found in agricultural fields. Our study corroborates the observation of comparatively low termite diversity in agro-ecosystems and confirms the hypotheses that termites are not resilient towards pronounced anthropogenic disturbance [50]. Termite diversity was found to be higher in less disturbed ecosystem as shown by [49] who found 19 and 15 termite genera in the primary forest and disturbed forest, respectively. Yet, the finding of significantly higher termite diversity in the organic highinput system demonstrates that farming practices such as applying compost, mulch and cover crops as well as irrigation can mitigate the negative effects of farming on termite diversity. In addition, these farming practices can have a positive effect on soil quality (see introduction and [14-21]), and might contribute to an improved productivity of maize crop in organic high-input system [28, 29].

However, a detailed study on yield losses/gains due to termite presence and activity was not done. Generally, since the beginning of the experiment yields of French beans in Org-High system were lower, but baby corn yields were similar or even higher to conventional systems [29]. During the study period, however, we found lower yields of baby corn in Org-High compared to Conv-High at Thika $(\sim 10 \%)$, which could be attributed to termite presence. The generally lower rainfalls at Thika could have most likely affected the availability of other food sources in the environment and thus termite colonies have to attack and forage on the crops grown in the plots for food given the dry spells. The preferred environment for termite activity was only given in the Org-High plots (see above), thus termite were searching for food there. This is also confirmed by our field observation and other authors noticing links between decreasing vegetation cover and crops becoming more susceptible to termite damage $[51,52]$. However, we cannot make a direct 
yield comparison from low input system to the baby corn yield in the Org-High because in the low input system a maize/bean intercrop was grown. Nonetheless, other authors could show positive links between termite presence and yield: [53] showed an yield increase of $36 \%$ in yield, which they suggest happen due to the improved soil water infiltration and improved soil nitrogen. However, due to experimental design (system experiment) it is only partially possible to link yield losses/gains to termite presence, because several factors influencing this parameter. Nonetheless, further studies on termite crop damage and associated yield losses are necessary.

\section{The effect of soil depths, trial sites and cropping seasons on termite abundance, incidence index and activity}

The large differences in termite abundance and incidence between the two sites (Chuka and Thika) can be explained by their geographical and agro-climatic differences. Chuka, lying in semi-humid climate and receiving more annual precipitation (1500-2400 mm), is likely to offer more favorable conditions for termite populations to thrive than Thika, which lies in sub-humid climate zone and receives between 900 and $1100 \mathrm{~mm}$ of rainfall, experiencing something of a moisture deficit, which would negatively affect termite's survival and reproduction rate. The absence of some genera (Allodontotermes and Ancistrotermes) at Thika might be also attributed to this. Other studies have made similar observations of termites showing that dry environments make them more vulnerable to desiccation and exposure $[54,55]$.

The differences in soils at the two sites might be another factor. Chuka has predominately clay and silt rich soils, whereas those at Thika have a lower clay content, another possible reason why Chuka supports higher termite populations. Refs. [56-58] have highlighted the importance of differences in soil texture on termite populations, which thrive better in clay and silt soils that optimize the termite's biological and chemical processes [24].

The abundance and incidence of termites in the substrate was also site dependent: At Thika there were more termites found in the substrate than at Chuka. Closer observation suggests that this could be related to the fairly large numbers of predatory ants found to be feeding on termites in the soil substrates at Chuka. This could have significantly lowered termite abundance in the substrate, especially as these ants were not observed at Thika in any of the three seasons. There was also a notable decline in termite abundance between the top and sub-soil, particularly at Thika. This could be because the top soil at Thika is shallow and bulky and underlain by a hard-pan subsoil. This soil structure is likely to influence both the organic matter content along soil profile and the moisture content which would further affect termite abundance, incidence and activity throughout the soil profile.

Termites often work intensively along the soil profile while foraging for food, thus creating galleries. We found that the incidence of galleries linearly and significantly declined between the soil profiles. This could be due to the lower food availability at lower soil profiles. Refs. [59-61] have come to similar findings. Termites generally prefer cellulose and ligneous materials which they initially shred at or near the soil surface, later transporting the broken-down materials deeper into the soil profiles where they shred them further, resulting in several galleries in the residue and soil levels. These galleries increase soil porosity as they create pathways for water to percolate deeper into the soil, and these were more evident at Chuka than Thika, probably due a higher termite abundance at Chuka. Refs. [20,62] report similar findings of greater numbers of poked holes in plots that are rich in organic material: due to the termites physically poking the soil structure. The higher moisture content of the soil at Chuka was a further biophysical characteristic difference that may have enhanced the presence of galleries at that site: a conclusion that is in line with other studies $[24,63,64]$.

When looking at the seasonal effects we noted that peak termite abundance occurred at both sites during the 2nd season, and was lower in the 1st and 3rd seasons. Our hypothesis for this lies in the crops grown in each season. During the 2nd season, with higher termite abundance, a predominately pure bean crop with a closed canopy was grown which may have been more favorable to termites as the less exposed soil surface would be better at retaining moisture, which is conducive for termite growth (see above).

\section{Conclusions}

The abundance of termites and castes, their incidence, foraging activities and diversity varied markedly between the conventional and organic farming systems. Termites, many of which are well known for their beneficial ecological roles, preferred the Org-High plots to the others. These other farming systems received no or far fewer organic inputs and lacked soil cover. These results suggest that the availability of organic matter and soil moisture in plots, along soil profiles could be one of the main determinants of termite abundance, activity and diversity. The findings demonstrates that farming practices such as applying compost, mulch and cover crops as well as irrigation can (partially) offset the disturbing effect that agriculture has on termite presence and provide a (relatively) attractive habitat for termites which, in turn, often have a beneficial effect on soil quality. 


\section{Materials and methods}

\section{Field sites}

The study was conducted between March 2014 and September 2015 in the ongoing Long-term Farming Systems Comparisons (SysCom) trials, situated in the sub-humid zones of the Central Highlands of Kenya (Fig. 3) at Chuka (Tharaka Nithi County, longitude $037^{\circ} 38.792^{\prime} \mathrm{N}$ and Latitude $00^{\circ} 20.864^{\prime} \mathrm{S}$ ) and at Thika (Murang'a County, longitude $037^{\circ} 04.747^{\prime} \mathrm{N}$ and latitude $\left.01^{\circ} 00.231^{\prime} \mathrm{S}\right)$. The two sites are situated in the upper midland $2\left(\mathrm{UM}_{2}\right)$ and upper midland $3\left(\mathrm{UM}_{3}\right)$ agro ecological zones which are described by [65] as main coffee and sunflower-maize zones, respectively. The areas are characterized by a bimodal rainfall pattern (a long rainy season from March to June and a short one from October to December) giving a mean annual rainfall of $1500 \mathrm{~mm}$ at Chuka and 900-1100 $\mathrm{mm}$ at Thika. The mean annual temperature ranges are from 19.2 to $20.6^{\circ} \mathrm{C}$ at Chuka and $19.5-20.7^{\circ} \mathrm{C}$ at Thika. Based on the FAO world reference base for soil resources, the soils at Chuka are Humic Nitisols while those at Thika are Rhodic Nitisols [66-68].

\section{Experimental design}

At each site, the trial compares conventional (Conv) and organic (Org) farming at two levels of inputs: high inputs (High) representing commercial large scale production and, low inputs (Low) representing small holder production, largely for subsistence use. The management practices of these four farming systems were applied on experimental plots of $8 \times 8 \mathrm{~m}\left(64 \mathrm{~m}^{2}\right.$; net plot $\left.6 \times 6 \mathrm{~m}^{2}\right)$ arranged in a Randomized Complete Block Design (RCBD), replicated four times in Chuka and five times in Thika. The termite study focused on the 1st season of 2014 (baby corn and maize-beans intercrop), the 2nd season of 2014 (French and common beans) and the 1 st season of 2015 (baby corn and maize-beans intercrop).

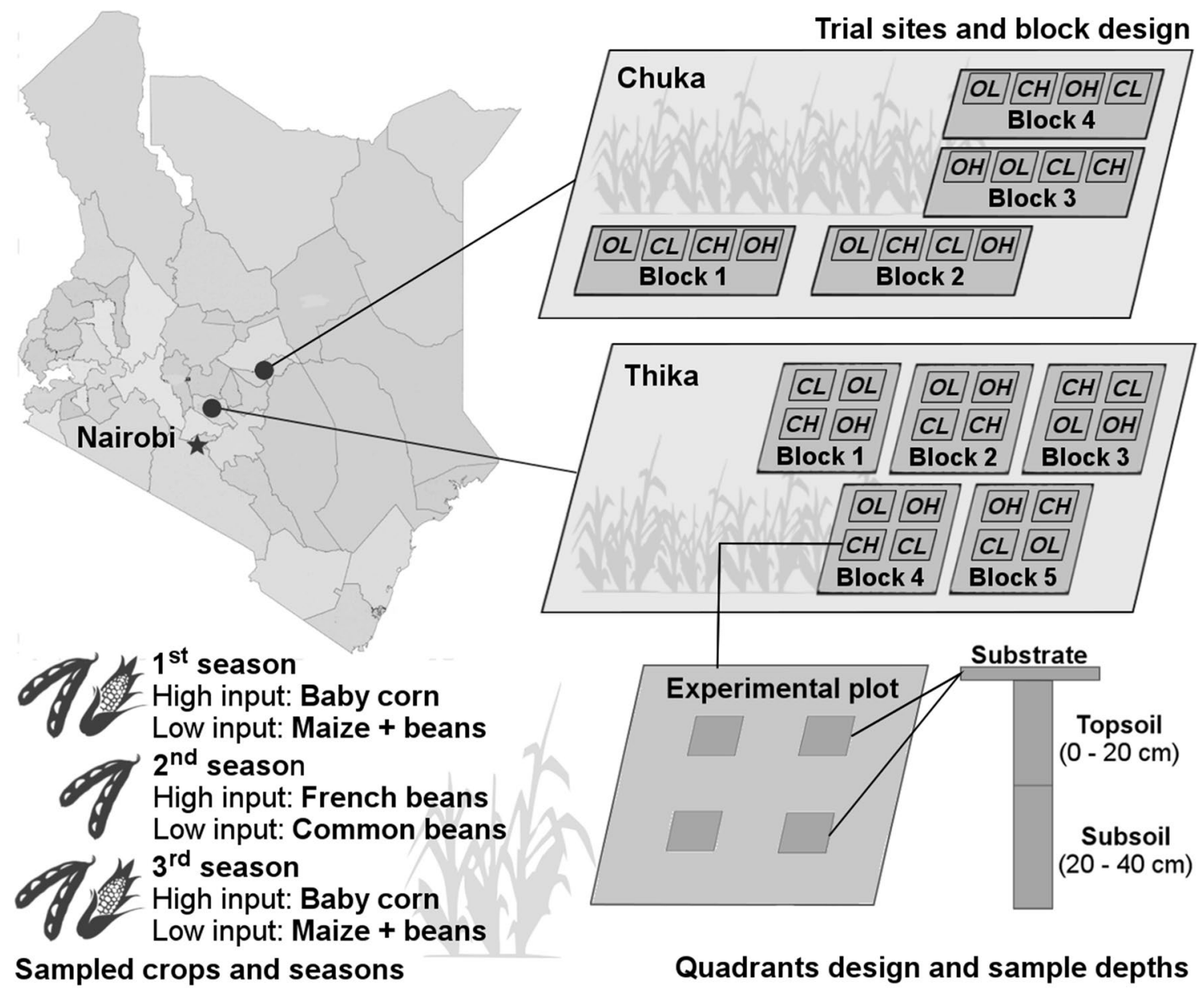

Fig. 3 The Farming Systems Comparison Trials in Kenya (SysCom). The trial sites, block design, sampled crops, cropping seasons, quadrant design and sample depths for the termite study in the long-term experiment at Chuka and Thika, the Central Highlands of Kenya (county map is derived and adapted from http://www.opendata.go.ke) 
Table 2 The details on fertility, pest and water management of the farming systems

\begin{tabular}{|c|c|c|c|c|c|c|c|c|}
\hline Farming system & Year & Season & Crop & $\begin{array}{l}\text { Fertilizer } \\
\text { management }\end{array}$ & $\begin{array}{l}\text { Total } \mathrm{N} \\
\text { applied } \\
\left(\mathrm{kg} \mathrm{ha}^{-1}\right)\end{array}$ & $\begin{array}{l}\text { Total P } \\
\text { applied } \\
\left(\mathrm{kg} \mathrm{ha}^{-1}\right)\end{array}$ & $\begin{array}{l}\text { Pest and disease } \\
\text { management }\end{array}$ & $\begin{array}{l}\text { Water } \\
\text { management }\end{array}$ \\
\hline \multirow[t]{3}{*}{ Conv-Low } & 2014 & LS & $\begin{array}{l}\text { Maize (Zea mays } \\
\text { var. H513)/Beans } \\
\text { (Phaseolus vulgaris } \\
\text { var. GLP 92) }\end{array}$ & $\begin{array}{c}5 \mathrm{t} \mathrm{ha}^{-1} \text { of fresh FYM, } \\
50 \mathrm{~kg} \mathrm{ha}^{-1} \text { DAP }\end{array}$ & 31 & 18 & Synthetic pesticides & Rain fed \\
\hline & 2014 & SS & $\begin{array}{l}\text { Common beans } \\
\text { (Phaseolus vulgaris } \\
\text { var. GLP 92) }\end{array}$ & $\begin{array}{l}\text { No fertilizer applica- } \\
\text { tion }\end{array}$ & NA & NA & & \\
\hline & 2015 & LS & $\begin{array}{l}\text { Maize (Zea mays } \\
\text { var. H513)/Beans } \\
\text { (Phaseolus vulgaris } \\
\text { var. GLP 92) }\end{array}$ & $\begin{array}{c}5 \mathrm{t} \mathrm{ha}^{-1} \text { of fresh FYM, } \\
50 \mathrm{~kg} \mathrm{ha}^{-1} \text { DAP }\end{array}$ & 31 & 18 & & \\
\hline \multirow[t]{3}{*}{ Org-Low } & 2014 & LS & $\begin{array}{l}\text { Maize (Zea mays } \\
\text { var. H513)/Beans } \\
\text { (Phaseolus vulgaris } \\
\text { var. GLP 92) }\end{array}$ & $\begin{array}{l}5 \mathrm{t} \mathrm{ha}^{-1} \text { FYM- } \\
\text { based compost, } \\
100 \mathrm{~kg} \mathrm{ha}^{-1} \mathrm{RP}, \\
136 \mathrm{~kg} \mathrm{ha}^{-1} \text { Titho- } \\
\text { nia mulch }\end{array}$ & 31 & 18 & Biological pesticide & Rain fed \\
\hline & 2014 & SS & $\begin{array}{l}\text { Common beans } \\
\text { (Phaseolus vulgaris } \\
\text { var. GLP 92) }\end{array}$ & $\begin{array}{l}\text { No fertilizer applica- } \\
\text { tion }\end{array}$ & NA & NA & & \\
\hline & 2015 & LS & $\begin{array}{l}\text { Maize (Zea mays } \\
\text { var. H513)/Beans } \\
\text { (Phaseolus vulgaris } \\
\text { var. GLP 92) }\end{array}$ & $\begin{array}{l}5 \text { t ha }^{-1} \text { FYM- } \\
\text { based compost, } \\
100 \mathrm{~kg} \mathrm{ha}^{-1} \mathrm{RP}, \\
136 \mathrm{~kg} \mathrm{ha}^{-1} \text { Titho- } \\
\text { nia mulch }\end{array}$ & 31 & 18 & & \\
\hline \multirow[t]{3}{*}{ Conv-High } & 2014 & LS & $\begin{array}{l}\text { Baby corn (Zea mays } \\
\text { var. Pannar 14) }\end{array}$ & $\begin{array}{l}113 \mathrm{t} \mathrm{ha}^{-1} \text { FYM, } \\
200 \mathrm{~kg} \mathrm{ha}^{-1} \text { DAP, } \\
100 \mathrm{~kg} \mathrm{ha}^{-1} \text { CAN }\end{array}$ & 113 & 60 & Synthetic pesticides & Irrigation \\
\hline & 2014 & SS & $\begin{array}{l}\text { French beans (Pha- } \\
\text { seolus vulgaris var. } \\
\text { Serengeti) }\end{array}$ & $\begin{array}{l}75 \mathrm{t} \mathrm{ha}^{-1} \text { FYM, } \\
200 \mathrm{~kg} \mathrm{ha}^{-1} \text { DAP, } \\
100 \mathrm{~kg} \mathrm{ha}^{-1} \text { CAN }\end{array}$ & 113 & 60 & & \\
\hline & 2015 & LS & $\begin{array}{l}\text { Baby corn (Zea mays } \\
\text { var. Pannar 14) }\end{array}$ & $\begin{array}{l}113 \mathrm{t} \mathrm{ha}^{-1} \mathrm{FYM} \\
200 \mathrm{~kg} \mathrm{ha}^{-1} \text { DAP, } \\
100 \mathrm{~kg} \mathrm{ha}^{-1} \text { CAN }\end{array}$ & 113 & 60 & & \\
\hline \multirow[t]{3}{*}{ Org-High } & 2014 & LS & $\begin{array}{l}\text { Baby corn (Zea } \\
\text { mays var. Pannar } \\
\text { 14)/Mucuna } \\
\text { pruriens }\end{array}$ & $\begin{array}{l}113 \mathrm{t} \mathrm{ha}^{-1} \text { FYM-com- } \\
\text { post, } 364 \mathrm{~kg} \mathrm{ha}^{-1} \\
\text { RP, } 54 \mathrm{t} \mathrm{ha}^{-1} \\
\text { Tithonia mulch and } \\
39 \mathrm{t} \mathrm{ha}^{-1} \text { Tithonia } \\
\text { tea }\end{array}$ & 113 & 60 & Biological pesticide & Irrigation \\
\hline & 2014 & SS & $\begin{array}{l}\text { French beans (Pha- } \\
\text { seolus vulgaris var. } \\
\text { Serengeti) }\end{array}$ & $\begin{array}{l}113 \mathrm{t} \mathrm{ha}^{-1} \text { FYM-com- } \\
\text { post, } 364 \mathrm{~kg} \mathrm{ha}^{-1} \\
\text { RP, } 54 \mathrm{t} \mathrm{ha}^{-1} \\
\text { Tithonia mulch and } \\
39 \mathrm{t} \mathrm{ha}^{-1} \text { Tithonia } \\
\text { tea }\end{array}$ & 113 & 60 & & \\
\hline & 2015 & LS & $\begin{array}{l}\text { Baby corn (Zea } \\
\text { mays var. Pannar } \\
\text { 14)/Mucuna } \\
\text { pruriens }\end{array}$ & $\begin{array}{l}113 \mathrm{t} \mathrm{ha}^{-1} \text { FYM-com- } \\
\text { post, } 364 \mathrm{~kg} \mathrm{ha}^{-1} \\
\text { RP, } 54 \mathrm{t} \mathrm{ha}^{-1} \\
\text { Tithonia mulch and } \\
39 \mathrm{t} \mathrm{ha}^{-1} \text { Tithonia } \\
\text { tea }\end{array}$ & 113 & 60 & & \\
\hline
\end{tabular}

The treatment details and the cropping pattern of the long-term farming systems comparisons trials at Chuka and Thika, the Central Highlands of Kenya ([29], modified); NB: Compost preparation starts with the indicated amount of FYM and was applied at planting; CAN was applied as top-dressing in two splits; Tithonian mulch was applied after crop germination as starter $\mathrm{N}$; The organic high input system also received maize stover and Mucuna intercropped with baby corn in the $1 \mathrm{st}$ season of 2014 and 2015 which was uprooted after harvest and incorporated following season; Assumptions: FYM/compost (DW): 1.12\% total N and 0.3\% P; The DM of FYM is assumed to be $40 \%$; Tithonia diversifolia (DW): 3.3\% N; $0.31 \%$ P; 3.1\% K; DM of Tithonia = 20\%; Phosphate rock from West Africa: $11-13 \%$ P

Conv-Low conventional low input farming system, Org-Low organic low input farming system, Conv-High conventional high input farming system, Org-High organic high input farming system, $L S$ long rain season, $S S$ short rain seasons, CAN calcium ammonium nitrate, DAP di-ammonium phosphate, TSP triple superphosphate, RP rock phosphate, FYM farm yard manure 
Details of field layout, crops grown, varieties, fertilizer and pest management inputs are summarized in Table 2 and graphically summarized in Fig. 3. Nonetheless, it has to be noted that pest and disease management and especially the termite control methods were different depending on site and system. At Chuka, no pesticide was used in all the systems and seasons to directly control termites. At Thika, we used the pesticides Dragnet (PyrethroidPermethrin; $\sim 20 \mathrm{~mL}$ in $5 \mathrm{~L}$; applied once) and Concord (Pyrethroid-Cypermethrin; $\sim 4 \mathrm{~mL}$ in $2 \mathrm{~L}$ water; applied twice) to purposely control termites in the conventional systems in the first season of 2014 and 2015, respectively. In the organic systems, we used icipe formulation no. 30 (fungus Metarhizium anisopliae) with different carrier materials (liquid: corn oil; solid: rice) to control termites in the same seasons. The formulation was used once in 2014 ( $2 \mathrm{~kg}$ solid carrier) and twice in 2015 (1.7 kg solid carrier as well as 4 and $5 \mathrm{~mL}$ liquid carrier in Org-Low and Org-High, respectively). Nonetheless, other pesticides were used during the study period to control pest and disease, and some of them have ingredients which also could influence termite behavior: Bestox (Pyrethroid), Bulldock (Pyrethroid), Folicur (Tebuconazole), Dynamic (Abamectin), Thiovit (Sulphur), Ortiva (Azoxystrobin), Duduthrin (Pyrethroid), and Rodazim (Carbendazim) in Conv-High, Halt (Bacillus thuringiensis), Fosphite (Potassium Phosphite), GC3 (garlic extract), Pyerin (Pyrethrum extract), Pyegar (Pyrethrum and garlic extract)), Nimbecidine (Neem-based) and Achook (Neem-based) in Org-High, and wood ash in low input systems.

\section{Data Collection}

\section{Termite sampling and identification}

A weekly termite sampling was carried every season from the 1st week after emergence (WAE) of the crop to the last harvesting day. Sampling was done in 4 quadrants within each experimental plot. Termites were sampled at different depths: (i) in the crop residue/litter on the soil surface $(100 \times 100 \mathrm{~cm}$; substrate); and (ii) in $10 \times 10 \times 10 \mathrm{~cm}$ monolith soil profiles at different soil depths of 0-20 (topsoil) and 20-40 cm (subsoil). Caste affiliation (worker, soldier, immature) of all sampled termites and genus of the sampled termite soldiers were determined in the field as much as possible by morphological assessments using a hand lens. Subsequently, the identification of soldier to genus level was confirmed at the Nairobi National Museum using standard determination keys $[69,70]$. The termites' foraging activity was assessed in every quadrant through (i) the length of tunneled soil surfaces and substrate $\left(\mathrm{cm}\right.$ per $\left.10,000 \mathrm{~cm}^{2}\right)$ and (ii) through the number of pocked holes/galleries at different top and subsoil (poked holes per $1000 \mathrm{~cm}^{3}$ ).

\section{Statistical data analysis}

After finishing sampling, over 24,400 data sets on the abundance of the total number of termites, termite castes and genera and on termite activity were entered into a database and validated (checked for double or missing entries). Each data set included information about the trial site, sampling season and date, block and plot number, farming system, quadrant number and sampling depth. The abundance data was used to calculate termite incidence per quadrant expressed as (a) the presence of termites (abundance $>0$ ) $=1$, and (b) the absence of termites (abundance $=0$ ) $=0$. Afterwards, all data on termite abundance and incidence per quadrant was summarized for each plot (substrate: $40,000 \mathrm{~cm}^{2}$; soil: $4000 \mathrm{~cm}^{3}$ ). The incidence data was then calculated as an incidence index ranging from 0 to 4 ( $0 \%$ presence to $100 \%$ presence in each plot). To characterize the diversity of termite (soldier) genera we used the software EstimateS [71] to determine species richness (S), the incidence-based coverage estimator of species richness (ICE), the Chao2 estimator of species richness, the Shannon index $\left(\mathrm{S}_{\mathrm{h}}\right)$ and inverse Simpson index $\left(\mathrm{S}_{\mathrm{i}}\right)$ as diversity measures.

Data sets were separated by sample depths prior to statistical analysis. One data set included data for abundance, the incidence index, tunneling activity and diversity measures in the substrate (expressed as per $40,000 \mathrm{~cm}^{2}$ soil surface), and the second data set included data for abundance, the incidence index, gallery activity and diversity measures in the top and subsoil (expressed as per $4000 \mathrm{~cm}^{3}$ soil volume). All data sets were analyzed using R statistical software version 3.2.5 [72]. Data was analyzed with a linear mixed effect model to determine the significant effects of the fixed factors using the lmer function from the lme4 package [73]. The model included 3 or 4 fixed factors: farming systems, cropping season, trial site and sampling depth (only for data relating to the top and subsoil) and their interactions, and one random factor (field replication-block). Computation of the estimated marginal means was done using the emmeans package [74], followed by mean separation using the adjusted Tukey's method using the multicompView package for cld function [75]. The correlation between termite castes and genera and between foraging activities was tested using the rcorr function from the Hmisc package [76]. The significance level for all tests was $\alpha=0.05$.

\section{Supplementary information}

Supplementary information accompanies this paper at https://doi. org/10.1186/s12898-020-00282-x.

Additional file 1: Table S1. The average abundance, incidence and activity of termites. Table S2. Diversity measures for termite genera. 


\begin{abstract}
Abbreviations
CAN: Calcium ammonium nitrate; Chao2: Chao's estimator of species richness; Conv-High: Conventional high farming system; Conv-Low: Conventional low input farming system; DAP: Di-ammonium phosphate; FYM: Farm yard manure; ICE: Incidence-based coverage estimator of species richness; LS: Long rain season; na: Not applicable; ns: Not significant; Org-High: Organic high input farming system; Org-Low: Organic low input farming system; RP: Rock phosphate; $S$ : Species richness; $S_{h}$ : Shannon index; $S_{j}$ : Inverse Simpson index; SS: Short rain seasons; TSP: Triple superphosphate.
\end{abstract}

\section{Acknowledgements}

The authors wish to acknowledge the financial support received from the Biovision Foundation for Ecological Development, Coop Sustainability Fund, the Liechtenstein Development Service (LED) and the Swiss Agency for Development and Cooperation (SDC). They also wish to thank the management of the Kenya Agricultural and Livestock Research Organization (KALRO; specifically including Dr. Waturu, Dr. Muriuki and Dr. Mbaka) for offering the trial site at Horticulture Research Institute (HRI) Thika and to the management of Kiereini Primary School for offering the second trial site at Chuka. We deeply appreciate the technical support received from SysCom Kenya team (Mrs. Jane Makena, Mr. J Kagendo and Mrs. Felistus Mutua) during data collection. We further appreciate the dedicated termite identification work at the National Museums Kenya (NMSK) laboratory under the guidance of Dr. Bagine and Mr. Morris. Finally, we extend our gratitude to the paper's external reviewers for their useful comments that helped further improve the manuscript and to Dr. Parrott of TextualHealing.eu for his English language editing.

\section{Authors' contributions}

$J A, N A, A M, K F, S S, Z L, M M, E K$ and $G O$ designed the termite sampling design. JA sampled the termite castes on the long-term experiments at Chuka and Thika. JA helped to identify the termite soldier at the lab and to validate the data. JA, JR and DB designed the statistical analysis, and analyzed and interpreted the termite data. DB prepared the figures for the manuscript. JA and $D B$ wrote the first draft. All authors made a revision of the first draft and JA/DB included all revision and comments. All authors read and approved the final manuscript.

\section{Funding}

This work was financially supported by Biovision Foundation, Coop Sustainability Fund, Liechtenstein Development Service (LED) and the Swiss Agency for Development and Cooperation (SDC). The funding bodies financially supported the setup and maintenance of the long-term experiments at Chuka and Thika in Kenya since 2006. The SysCom team was responsible for the design of the study, collection, analysis, and interpretation of the data and in writing the manuscript.

\section{Availability of data and materials}

The datasets used and analyzed during the current study are available from the corresponding author on reasonable request. As we are working on a long-term experiment, we are establishing our own (SharePoint) database to store all available data. This database is not public as not all the data in the database is yet published, but the database can be accessed through a request addressing the project team at FiBL (http://systems-comparison.fibl. org/).

\section{Ethics approval and consent to participate}

The study on termite abundance and diversity was part of the SysCom program. The program was initiated and is coordinated by the Research Institute of Organic Agriculture (FiBL Switzerland). The implementation of the long-term experiment in Kenya is done by the main partners the International Centre of Insect Physiology and Ecology (icipe) and the Kenya Agricultural and Livestock Research Organization (KALRO). The study was carried out as a Ph.D. project of Mr. John J Anyango in cooperation with the institutions mentioned above and the Zoology Department of the Jomo Kenyatta University of Agriculture and Technology (JKUAT) in Nairobi, Kenya.

\section{Consent for publication}

Not applicable.

\section{Competing interests}

The authors declare that they have no competing interests.

\section{Author details}

${ }^{1}$ International Centre of Insect Physiology and Ecology (icipe), P.O. Box 30772-00100, Nairobi, Kenya. ${ }^{2}$ Kenya Agricultural and Livestock Research Organization (KALRO), Nairobi, Kenya. ${ }^{3}$ Department of International Cooperation, Research Institute of Organic Agriculture (FiBL), Ackerstrasse 113, P.O. Box 219, 5070 Frick, Switzerland. ${ }^{4}$ Zoology Department, Jomo Kenyatta University of Agriculture and Technology, Nairobi, Kenya. ${ }^{5}$ Department of Plant Science, Research Institute of Organic Agriculture (FiBL), Ackerstrasse 113, P.O. Box 219, 5070 Frick, Switzerland.

Received: 24 July 2018 Accepted: 20 February 2020

Published online: 27 February 2020

\section{References}

1. Sanchez PA. Soil fertility and hunger in Africa. Science. 2002;129:2019-20.

2. Coq S, Barthes BG, Oliver R, Rabary B, Blenchart E. Earthworm activity affect soil aggregation and organic matter dynamic according to the quality and localization of crop residues - an experiment study (Madagascar). Soil Biol Biochem. 2007;39(8):2119-28.

3. Sileshi GW, Nyeko P, Nkunika POY, Sekematte BM, Akinnifesi FK, Ajayi OC. Integrating ethno-ecological and scientific knowledge of termites for sustainable termite management and human welfare in Africa. Ecol Soc. 2009;14(1):48.

4. Sileshi G, Kuntashula E, Matakala P, Nkunika PO. Farmers' perceptions of pests and pest management practices in agroforestry in Malawi, Mozambique and Zambia. Agrofor Syst. 2008;72:87-101.

5. Mitchell JD. Termites as pests of crops, forestry, rangeland and structures in southern Africa and their control. Sociobiology. 2002;40:47-69.

6. Ayuke FO. Soil macrofauna functional groups and their effects on soil structure, as related to agricultural management practices across agroecological zones of Sub-Saharan Africa. Ph.D. thesis. Wageningen University, Netherlands. 2010.

7. Sileshi G, Mafongoya PL, Kwesiga F, Nkunika P. Termite damage to maize grown in agroforestry systems, traditional fallows and monoculture on nitrogen-limited soils in eastern Zambia. Agric For Entomol. 2005;7:61-9.

8. Blum A. Breeding methods for drought resistance, plants under stress. Cambridge: Cambridge University Press; 1989.

9. Tenywa G. Thousands homeless as termites turn Nakasongola into a desert. The New Vision. 2008. http://www.newvisioncoug/D/9/36/63558 5?highlight\&q=termite. Accessed 23 Apr 2015.

10. Peveling R, McWilliam AN, Nagel P, Rasolomanana H, Raholijaona A, Rakotomianina L, Ravoninjatovo, Dewhurst CF, Gibson G, Rafonomezana S, Tingle CCD. Impact of locust control on harvester termites and endemic vertebrate predators in Madagascar. J Appl Ecol. 2003;40:729-41.

11. Dawes-Gromadzki TZ. The termite (Isoptera) fauna of a monsoonal rainforest near Darwin, northern Australia. Aust Entomol. 2005;44:152-7.

12. UNEP. Balancing the benefits of chemicals with their health and environmental risks. Ind Environ. 2000;27(3):3.

13. Su NY. Novel technologies for subterranean termite control. Sociobiology. 2002;40:95-101.

14. Adekayode FO, Ogunkoya MO. Comparative study of clay and organic matter content of termite mounds and the surrounding soils. In: African crop science conference proceedings. 2009; p. 9.

15. Mando A, Brussard L, Stroosnijder L. Termite- and mulch-mediated rehabilitation of vegetation on crusted soil in West Africa. Restor Ecol. 1999;7:33-41.

16. Chikuvire TJ, Mpepereki S, Foti R. Long-term impact of reduced tillage and residue management on soil carbon stabilization: implications for conservation agriculture on contrasting soils. J Sustain Agric. 2007;30:69-87.

17. Asawalam DO, Johnson S. Physical and chemical characteristics of soils modified by earthworms and termites. Commun Soil Sci Plant Anal. 2007;38:513-21.

18. Ackerman IL, Teixeira WG, Riha SJ, Lehmann J, Fernandes EC. The impact of mound-building termites on surface soil properties in a secondary forest of Central Amazonia. Appl Soil Ecol. 2007:37:267-76.

19. Pardeshi M, Prusty BAK. Termites as ecosystem engineers and potentials for soil restoration. Curr Sci. 2010;99:11.

20. Turner SJ, et al. Termites, water and soils. Agricola. 2006;16:40-5. 
21. Manuwa SI. Physico-chemical and dynamic properties of termite mound soil relevant in sustainable food production. In: African crop science conference proceedings, Uganda. 2009; pp. 365-9.

22. Okwakol MJN, Sekamatte MB. Soil macrofauna research in ecosystems in Uganda. Afr J Ecol. 2007;45(2):2-8.

23. Siame AJ. Termite mound as fertilizer low external input. Sustain Agric. 2005;21:29-31.

24. Nhamo $\mathrm{N}$. The contribution of different fauna communities to improved soil health: a case of Zimbabwean soils under conservation agriculture. Ecol Dev. 2007;56:131.

25. Kladivko EJ. Tillage systems and soil ecology. Soi Till Res. 2001;61:61-76.

26. Giller KE, Witter $\mathrm{E}$, Corbeels M, Tittonell P. Conservation agriculture and smallholder farming in Africa: the heretics' view. Field Crops Res. 2009;114:23-34

27. Colloff MJ, Pullen KR, Cunningham SA. Restoration of an ecosystem function to revegetation communities: the role of invertebrate macropores in enhancing soil water infiltration. Restor Ecol. 2010;18(s1):65-72.

28. Farming systems comparisons trials in the tropics (SysCom). Research Institute of Organic Agriculture (FiBL). 2018. http://systems-comparison .fibl.org/. Accessed 24 Feb 2020.

29. Adamtey N, Musyoka MW, Zundel C, Cobo GJ, Karanja E, Fiaboe KKM, Muriuki A, Mucheru-Muna M, Vanlauwe B, Berst E, Messmer MM, Gattinger A, Bhullar GS, Cadisch G, Fliessbach A, Mader P, Niggli U, Foster D. Productivity, profitability and partial nutrient balance in maize-based conventional and organic farming systems in Kenya. Agric Ecosyst Environ. 2016;235:61-79.

30. De Souza OF, Brown VK. Effects of habitat fragmentation on Amazonian termite communities. J Trop Ecol. 2009;10(2):197-206.

31. Freymann BP, Buitenwerf R, Desouza O, Olff $H$. The importance of termites (Isoptera) for the recycling of herbivore dung in tropical ecosystems: a review. Eur J Entomol. 2008;105(2):165-73.

32. Bignell DE, Roisin Y, Lo N. Biology of termites: a modern synthesis. 1st ed. Dordrecht: Springer; 2010.

33. Barrios E. Soil biota ecosystem services and land productivity. Ecol Econ. 2007;64:269-85.

34. Ngosong C, Mfombep PM, Njume AC, Tening AS. Integrated soil fertility management: impact of mucuna and tithonia biomass on tomato (LyCopersicon esculentum $\mathrm{L}$ ) performance in smallholder farming systems. Agric Sci. 2015;6:1176-86.

35. Abdourhamane Touré A, Guillon R, Garba Z, Rajot JL, Petit C, Bichet V, Durand A, Sebag D. Sahelian landscape evolution during the six last decades in the Niamey vicinity: from the bush disappearing to the soil crusting. Pangea. 2011;47:35-40.

36. Akol AM, Chidege MY, Talwana HA, Mauremootoo JR. Invertebrate pests of maize in East Africa (Kenya, Uganda and Tanzania), Lucid v. 3.5 key and fact sheets. Makerere: Makerere University, TPRI, BioNET-EAFRINET, CABI \& the University of Queensland; 2011.

37. Asogwa EU, Okelana FA, Ndubuaku TCN, Mokwunye IU. The termicidal effects of Chlorpyrifos 48 EC, Endosulfan 35 EC, Dichlorvos 1000 EC and Diazinon 600 EC against termites in South-West Nigeria. Afr J Biotechnol. 2009; 8(1).

38. Ojiako FO, Dialoke SA, Ihejirika GO, Ahuchaogu CE, Ohiri CP. Comparative performance of pyrethrum [Chrysanthemum cinerariifolium Treviranus (Vis.)] extract and cypermethrin on some field insect pests of Groundnut (Arachis hypogaea L.) in Southeastern Nigeria. Am J Exp Agric. 2015;7(2):96.

39. Nyagumbo I, Munamati M, Mutsamba EF, Thierfelder C, Cumbane A, Dias D. The effects of tillage, mulching and termite control strategies on termite activity and maize yield under conservation agriculture in Mozambique. Crop Prot. 2015;78:54-62.

40. Orikiriza L, Nyeko P, Sekamatte B. Farmers'knowledge, perceptions and control of pestiferous termites in Nakasongola district, Uganda. Uganda J Agric Sci. 2012;13(1):71-83.

41. Maniania NK, Ekesi S, Songa MJ. Managing termites in maize with the entomopathogenic fungus Metarhizium anisopliae. Int J Trop Insect Sci. 2002;22(1):41-6.

42. Thatheyus AJ, Selvam A, Gnana D. Synthetic pyrethroids: toxicity and biodegradation. Appl Ecol Environ Sci. 2013;1(3):33-6.

43. De Silva PMC, Pathiratne A, van Straalen NM, van Gestel CA. Chlorpyrifos causes decreased organic matter decomposition by suppressing earthworm and termite communities in tropical soil. Environ Pollut. 2010;158(10):3041-7.

44. Verma S, Sharma S, Malik A. Termiticidal and repellency efficacy of botanicals against Odontotermes obesus. Int J Res Biosci. 2016;5(2):52-9.

45. Shiberu T, Ashagre H, Negeri M. Laboratory evaluation of different botanicals for the control of termite, Microterms spp (Isoptera: Termitidae). 2013; 2:696. https://doi.org/10.4172/scientificreports.696.

46. Jirnmci E. Efficacy of botanical extracts against termites, Macrotermes spp., (Isoptera: Termiticlae) under laboratory conditions. Agric Res. 2014;9(2):60-73.

47. Osipitan AA, Oseyemi AE. Evaluation of the bio-insecticidal potential of some tropical plant extracts against termite (Termitidae: isoptera) in Ogun State, Nigeria. J Entomol. 2012;9(5):257-65.

48. Muvengi J, Mbiba M, Ndagurwa HGT, Nyamadzawo G, Nhokovedzo P. Termite diversity along a land use intensification gradient in a semi-arid savanna. J Insect Conserv. 2007;21:801-12.

49. Olugbemi BO. Termite assemblages and decomposition of tissue paper baits along a gradient of land use intensification in Owena, Southwest Nigeria. Appl Ecol Environ Res. 2013;11(2):223-35.

50. Coulibaly T, Akpesse AAM, Boga J-P, Yapi A, Kouassi KP, Roisin Y. Change in termite communities along a chronosequence of mango tree orchards in the north of Côte d'Ivoire. J Insect Conserv. 2016;20(6):1011-9.

51. Debelo DG, Degaga G. Farmers knowledge, perceptions and management practices of termites in the central rift valley of Ethiopia. Afr J Agric Res. 2015;10(36):3625-35.

52. Mugerwa S, Nyangito M, Nderitu J, Bakuneta C, Mpairwe D, Zziwa E. Farmers ethno-ecological knowledge of the termite problem in semi-arid Nakasongola. Afr J Agric Res. 2011;6(13):3183-91.

53. Evans TA, Dawes TZ, Ward PR, Lo N. Ants and termites increase crop yield in a dry climate. Nat Commun. 2011;2:262.

54. Potter MF. Termites. In: Mallis A, Hedges SA, Moreland D, editors. Handbook of pest control 9. Cleveland: GIE Media Inc.; 2004. p. 217-361.

55. Jouquet $P$, Dauber J, Lagerlöf J, Lavelle P, Lepage M. Soil invertebrates as ecosystem engineers: intended and accidental effects on soil and feedback loops. Appl Soil Ecol. 2006;32(2):153-64.

56. Bhanot JP, Sharma AK, Batra GR, Verma AN. Influence of different levels of irrigation and fertilizer application on termite damage and yield of gram crop raised from aldrin-treated and untreated seed. J Insect Sci. 1994;7(1):115-6.

57. Pearce MJ. Termites: biology and pest management. Oxon: CAB International; 1997.

58. Jouquet $P$, Tessier $D$, Lepage $M$. The soil structural stability of termite nests: role of clays in Macrotermes bellicosus (Isoptera: Macrotermitinae) mound soils. Eur J Soil Biol. 2004;40:23-9.

59. Cornelius ML, Osbrink WL. Effect of soil type and moisture availability on the foraging behavior of the Formosan subterranean termite (Isoptera: Rhinotermitidae). J Econ Entomol. 2010;103(3):799-807.

60. Zida Z, Ouedraogo E, Mando A, Stroosnijder E. Termite and earthworm abundance and taxonomic richness under long-term conservation soil management in Saria, Burkina Faso, West Africa. Appl Soil Ecol. 2011;51:22-129.

61. Mutema M, Mafongoya PL, Nyagumbo I, Chikukura L. Effects of crop residues and reduced tillage on macrofauna abundance. J Org Syst. 2013;8(1):5-16.

62. Houseman RM, Gold RE. Factors that influence tunneling in the eastern subterranean termite, Reticulitermes flavipes (Kollar) (Isoptera: Rhinotermitidae). J Agric Urban Entomol. 2003;20:69-81.

63. Arab A, Costa-Leonardo AM. Effect of biotic and abiotic factors on the tunneling behavior of Coptotermes gestroi and Heterotermes tenuis (Isoptera: Rhinotermitidae). Behav Process. 2005;70:32-40.

64. Green JM, Scharf ME, Bennett GW. Impacts of soil moisture level on consumption and movement of three sympatric subterranean termites (Isoptera: Rhinotermitidae) in a laboratory assay. J Econ Entomol. 2005;98:933-7.

65. Jaetzold R, Schmidt H, Hornetz B, Shisanya C. Farm management handbook of Kenya Vol II-Natural conditions and farm management information. 2nd edn. Ministry of Agriculture, Kenya, in cooperation with the German Agency for Technical Cooperation (GTZ). 2006.

66. IUSS Working Group WRB. World reference base for soil resources. 2nd edn. World Soil Resources Reports No 103 FAO, Rome. 2006. 
67. Wagate PN, Njoroge CRK, Macharia PN, Chek AL. The soil conditions of icipe experimental plot, Thika Horticultural Research Centre, Muranga South District Kenya. Detailed Soil Survey Report D84, Nairobi. 2010 a.

68. Wagate PN, Njoroge CRK, Macharia PN, Chek AL. The soil conditions of icipe experimental farm at Kiereini primary school, Chuka (Meru South District) Kenya. Detailed Soil Survey Report D85, Nairobi. 2010b.

69. Webb GC. Keys to the genera of the African Termites. Ibadan: Ibadan University Press; 1961.

70. Sekamatte MB. Options for integrated management of termites (Isoptera: Termitidae) in smallholder maize-based cropping systems in Uganda. Ph.D. thesis Kampala: Makerere. 2001.

71. Colwell RK. EstimateS: statistical estimation of species richness and shared species from samples. 2013. http://www.viceroyeebuconnedu/ estimates.

72. R Development Core Team. A language and environment for statistical computing Vienna: The R Foundation for Statistical Computing. 2005. http://www.R-projectorg/.
73. Bates $D$, Maechler M, Bolker B, Walker S. Fitting linear mixed-effects models using Ime4. J Stat Softw. 2015;67(1):1-48. https://doi.org/10.18637/jss. v067.i01.

74. Lenth R. emmeans: Estimated Marginal Means, aka Least-Squares Means R package version 091. 2017. https://www.CRANR-projectorg/packa ge=emmeans.

75. Pierpho HP. An algorithm for a letter-based representation of all-pairwise comparisons. J Comput Gr Stat. 2004;13(2):456-66.

76. Harrell FE Jr, Dupont C. Hmisc: Harrell Miscellaneous. 2016. http://www. CRANRprojectorg/package $=$ Hmisc.

\section{Publisher's Note}

Springer Nature remains neutral with regard to jurisdictional claims in published maps and institutional affiliations.
Ready to submit your research? Choose BMC and benefit from:

- fast, convenient online submission

- thorough peer review by experienced researchers in your field

- rapid publication on acceptance

- support for research data, including large and complex data types

- gold Open Access which fosters wider collaboration and increased citations

- maximum visibility for your research: over 100M website views per year

At BMC, research is always in progress.

Learn more biomedcentral.com/submissions 